\title{
CARDIOSPERMUM HALICACABUM LINN. - A REVIEW
}

\author{
SAVITHA G*, VISHNUPRIYA V, SURAPANENI KRISHNAMOHAN
}

Department of Biochemistry, Saveetha Dental College, Saveetha University, Chennai, Tamil Nadu, India. Email: drsavitha80@gmail.com Received: 27 May 2017, Revised and Accepted: 14 June 2017

\begin{abstract}
Before the modern day, medicine and its pharmacopeia of synthetic drugs, there were plants and ancient civilizations knew how to use the plants strategically to treat common ailments and even life-threatening diseases. Natural plant-based remedies are used for the both acute and chronic health problems from treating common colds to control blood pressure and cholesterol. Plant medicines were the most widely used medicines in the world because of their safety and very less or no side effects. In this way, the aim of this review article was to summarize the phytochemical and medicinal information of the readily reachable plant Cardiospermum halicacabum Linn. This is commonly known as Balloon vine extensively dispersed in tropical and subtropical areas of world. The roots, leaves, stem, and seeds of this plant are employed as herbal medication. The phytochemical analysis confirmed that this herb contains flavonoids, terpenoids, tannins, saponin, protein, carbohydrates, glycosides, variety of fatty acids, and volatile esters. Due to the presence of various compounds, this plant has antibacterial, antifungal, antiparasitic, antidiarrheal, anxiolytic, antioxidant, antipyretic, antirheumatic, anticonvulsant, anti-inflammatory, and anticancinogenic activities.
\end{abstract}

Keywords: Cardiospermum halicacabum, Antibacterial, Antifungal, Antiparasitic, Antidiarrheal, Anxiolytic, Antioxidant, Antipyretic, Antirheumatic, Anticonvulsant, Anti-inflammatory, Neuroprotective, Anticancinogenic.

(C) 2017 The Authors. Published by Innovare Academic Sciences Pvt Ltd. This is an open access article under the CC BY license (http://creativecommons. org/licenses/by/4. 0/) DOI: http://dx.doi.org/10.22159/ajpcr.2017.v10i10.20261

\section{INTRODUCTION}

Now a days, herbal medicines play a major role in health-care programs in developing countries. Around $80 \%$ of world population still depends on medicinal plants for their primary health-care needs [1]. India is recognized as a land of herbal plants; hence, any specific data on such plants could be of clinical importance [2].

C. halicacabum Linn. belongs to family Sapindaceae. Common name is Balloon vine. Tamil name Mudakkathan. Annual climber stems with minutely puberulous, tendrils present. Leaves biternate, essentially trifoliate with each part divided again into 3 leaflets, leaflets with coarse serrate teeth. Flowers in the axillary heads usually 3 flowered by abortion, white with a yellowish center. Fruit a membranous, inflated capsule, green, drying to brown more than $2 \mathrm{~cm}$ long. Round and black seeds with a broadly heart-shaped or kidney-shaped spot [3].

This plant is extensively dispersed in tropical and subtropical areas of the world. This plant is produced in the plains of Africa, America, Bangladesh, India, and Pakistan [4].

For several centuries, the whole plant has been used for treatment of rheumatism, stiffness of limbs, snake bite, its root for nervous diseases, as a diaphoretic, diuretic, emetic, emmenagogue, laxative, refrigerant, stomachic, and sudorific; its leaves and stalks are used in the treatment of diarrhea, dysentery, and headache and as a poultice for swellings [5]. It is used for the treatment of skeletal fractures in Srilanka [6]. Various products such as gel, cream, shampoo, and spray of $C$. halicacabum is available in market. These products are useful for dry itchy skin and scalp [6]. Many studies show extract of $C$. halicacabum has pronounced anticarcinogenic activity also.

\section{PHYTOCHEMICAL CONSTITUENTS}

Phytochemical analysis of the $C$. halicacabum showed presence of carbohydrate, protein, lipids, saponins, tannins, flavonoids, alkaloids, glycosides, and steroids [1,3,6,7]. Gas chromatography - mass spectrometry analysis of this plant extract revealed presence of many active compounds in $C$. halicacabum such as 1,2,4-trioxolane2-octanic acid, 5-octyl-methyl ester, ethanol, 2-[9-octadecenyloxyl], 1,2,4-Trioxolane-2-octanic acid, 5 octyl methyl ester, ricinolenic acid, [1,1-bicyclopopyl]-2-octanic acid, 2-hexyl-methyl ester, 11-octadecenoic acid, methyl ester, 7-methyl-7tetradecan-1-ol acetate, oleic acid, 9-octadecenoic acid, 1,2,3-propanetriyl ester [8]. (+)- pinitol, $\beta$ sitosterol, $\beta$ sitosterol- $\beta$-o-glactoside, apigenin-7-o-glucuronide, arachidic acid, chryoerior-7-o-glucuronide, linoleic acid, luteolin-7-oglucuronide, and stearic acid [9].

\section{THERAPEUTIC USES}

Because of the presence of various chemical constituents, extract of this plant showed various medicinal properties such as antibacterial, antifungal, antiparasitic, antidiarrhoeal, anxiolytic, rubifacient, antipyretic, anti-inflammatory, anticonvulsant, and anticarcinogenic.

\section{Antibacterial activity}

In recent years, the rate of infection and resistant against antibiotics has been increased. The presence of antibacterial substances in the plant show good antibacterial activity without producing any side effects. Antibacterial activity of $C$. halicacabum Linn. was investigated by well diffusion technique (Farrukh et al., 2008) against the selected human pathogens. This extract showed varying degrees of inhibition zones against Gram-positive bacteria (Staphylococcus aureus, S. aureus AB 188, Staphylococcus epidermis, Streptococcus pyogenes, Streptococcus fecalis, Bacillus subtilis, Bacillus cereus, Bacillus steadher, Micrococcus luteus, Corynebacterium hofmanu, and Pnemococci) and Gram-negative bacteria (Shigella boydii, Shigella dysenterae, Salmonella typii, Salmonella paratyphii A, Salmonella parathypii B, Shigella flexneri, Proteus flexneri, Proteus mirabilis, Proteus vulgaris, Escherichia coli, Klebsiella pneumonia, Enterobacter, and Pseudomonas aeroginosa) [2,5,7,9-11].

\section{Antifungal activity}

Antifungal activity of plant extract was carried out according to Mahmud et al., 2009 by agar dilution method. The extract of $C$. halicacabum Linn. showed significant antifungal activity against human pathogens (Aspergillus niger, Candida albicans), animal pathogens (Microsporillum 
gypsiccus, Trichophyton mentagrophyte) and plant pathogens (Saccharomyces cerevisiae, Penicillium sp.) [1,2,11].

\section{Antiparasitic activity}

Extracts of $C$. halicacabum were tested in in vitro for their effectiveness against third-stage larvae of Strongyloides stercoralis. This is an important parasitic nematode which persists for years in the human host and it may disseminate and cause fetal infection. Aqueous extract of $C$. halicacabum exerted more rapid effect on larval motility than that of the alcohol extract. To attain $50 \%$ non motility or dead it took $<24 \mathrm{hrs}$ and more than $36 \mathrm{hrs}$ for aqueous and alcohol extract of $C$. halicacabum, respectively [12].

\section{Anti-inflammatory activity}

$\lambda$-Carrageenan hind paw edema model was used for determination of anti-inflammatory activity [13,14]. The L-arginine-NO pathway has been proposed to play an important role in the carr-induced inflammatory response. The expression of inducible isoform of NO synthase is an important mediator of inflammation. Therefore, the NO level has been increased during inflammation.

Tumor necrosis factor (TNF- $\alpha$ ) is a major mediator in inflammatory responses. It induces innate immune responses by activating $\mathrm{T}$ cells and macrophages and increase the secretion of other inflammatory cytokines $[13,14]$.

The ethanolic extract $(100,200$, and $400 \mathrm{mg} / \mathrm{kg})$ significantly decreased the NO level in serum and TNF- $\alpha$ level in serum after 5 hrs of post-Carr injection [13]. By inhibiting the NO and TNF- $\alpha$ production, C. halicacabum expressed its anti-inflammatory activity [15].

Extract of C. halicacabum Linn. contained rutin. Rutin is a flavonol glycoside comprised flavonol quercetin and the disaccharide runinose. Rutin was shown to increase the colonic glutathione level, thus reducing oxidative tissue damage and thus reduce the inflammation [16].

\section{Antioxidant activity}

Reactive oxygen species affects various molecular components of the cell such as fatty acids, proteins, and DNA. An excess production of reactive oxygen species leads to cell degeneration and death [17]. Methanolic extract of C. halicacabum exhibited inhibition of 2,2-diphenyl-1picrylhydrazyl radical and possessed reducing power, superoxide scavenging ability, nitric oxide scavenging activity, and ferrous ion chelating potency $[9,18,19]$. Large quantities of phenolic compounds in C. halicacabum extract makes it a strong free radical scavenger, which indicates that the extract has good potential as a source for natural antioxidants to prevent free radical-mediated oxidative damage [20].

\section{Antipyretic activity}

Antipyretic activity of the $C$. halicacabum Linn. extract was studied in rat models. For this, pyrexia was induced by pyrogen administration. Ethanolic and n-hexane extract of the $C$. halicacabum showed significant antipyretic activity at a higher dose of $400 \mathrm{mg} / \mathrm{kg}$. The efficacy of $100 \mathrm{mg} / \mathrm{kg}$ paracetamol was almost equal to that of $400 \mathrm{mg} / \mathrm{kg}$ of the extract $[1,21]$.

\section{Antidiarrhoeal activity}

Diarrhea is a very common and major national problem in many tropical countries which results in 4-5 million deaths throughout the world annually [22]. Diarrhea was induced by castor oil to the animal models. The alcoholic and aqueous extract of the C. halicacabum exhibited the antidiarrhoeal activity against the castor oil induced diarrhea by reducing the frequency of defecation and decrease the intestinal secretion $[23,24]$.

\section{Antiarthritic activity}

Rheumatoid arthritis is an autoimmune disease which results in a chronic, systemic inflammatory disorder that causes pain, swelling, stiffness, and loss of function in joints [25]. Liquid chromatography mass spectrometry analysis of $C$. halicacabum indicated the presence of anti-inflammatory compounds Luteolin-7-o-glucuronide, Apigenin7-o-glucuronide, and Chrysoeriol [26-28]. Extract of the C. halicacabum exhibited therapeutic effects against Freund's complete adjuvantinduced arthritis in rat models by decreasing the production of proinflammatory cytokines such as TNF- $\alpha$, interleukin-1 [29] and inhibition of protein denaturation, membrane stabilization and proteinase inhibition $[30,31]$.

\section{Anxiolytic activity}

The state of anxiety involves disturbances in coordination of different neurotransmitters, for example, gamma amino butyric acid (GABA), serotonin, noradrenalin, dopamine, opoid peptides, endocannabinoids, corticotrophin-releasing hormone, neuropeptide $Y$, and oxytocin in various brain pathways [32]. GABA is a major inhibitory neurotransmitter in the central nervous system and activation of $\mathrm{GABA}_{\mathrm{A}}$ receptors results in significant increase in chloride conductance across the cell membrane which causes neuronal failure to generate an action potential and leads to inhibition. C. halicacabum extract has various bioactive compounds such as flavonoids, sterols, triterpenoids, saponin, tannins, and xanthoproteins [33-35]. Anxiolytic activity of the extract may be due to binding of any of these phytochemicals to the $\mathrm{GABA}_{\mathrm{A}^{-}}$ $\mathrm{BZD}_{\mathrm{S}}$ complex [32].

\section{Antidiabetic activity}

Diabetes mellitus is a metabolic disorder which is characterized by a loss of glucose homeostasis with disturbances of carbohydrate, fat, and protein metabolism resulting from defects in insulin secretion or insulin action or both. Management of diabetes without any side effect is still challenge to the medical community [36,37]. Antihyperglycemic effect of ethanolic extract of $C$. halicacabum leaf was examined against streptozotocin-induced diabetic rats. This extract has several flavonoids such as apigenin, pinitol, and luteolin which are reported as the antidiabetic principles [38,39]. This extract showed significant antihyperglyceamic activity at the dose of $200 \mathrm{mg} / \mathrm{kg}$ by decreasing the plasma glucose and $\mathrm{HbA}_{1} \mathrm{C}$ and increasing the level of insulin and hemoglobin. This extract increased the activity of glucokinase and decreased the activity of glucose 6 phosphatase and fructose 1,6 phosphatase in the liver $[38,40]$. Thus, this extract showed antidiabetic activity [41].

\section{Anticonvulsant activity}

Alcoholic extract of the petroleum ether fraction of $C$. halicacabum in the dose of $350 \mathrm{mg} / \mathrm{kg}$ body weight was effectively reduced the extensor and flexor component of tonic convulsions in electroshockinduced convulsions in Wistar rats $[1,41,42]$.

\section{NEUROPROTECTIVE ROLE}

Dementia is a progressive brain dysfunction which leads to a gradually increasing restriction of daily activities. It is characterized by difficulties in memory, disturbances in language, psychological and psychiatric changes, and impairment in routine activities. Methanolic extract of $C$. halicacabum potentially improved memory and reversed amnesia induced by administration of scopolamine. It also significantly decreased the whole brain acetyl cholinesterase activity [43].

\section{Anticancer activity}

Cancer is a second major cause of deaths after cardiovascular diseases. The available anticancer therapies not only kill the cancer cells but kill the normal cells also [9]. Due to the presence of phytocompounds, the extract of $C$. halicacabum showed anticancer activity. Methanolic extract of the $C$. halicacabum showed remarkable anticancer potential against the breast cancer cell lines $[44,45]$. Chloroform extract of $C$. halicacabum Linn. showed significant anticancer activity against Ehrlich Ascites carcinoma cell line [9]. Methanolic extract of $C$. halicacabum has profound effect in controlling Hep-G2 cell proliferation at lower 
concentration [8]. Evaluation of cytotoxic activity of $C$. halicacabum using MTT assay revealed that $C$. halicacabum extract is a potential material for the treatment of cancer [46].

\section{CONCLUSION}

C. halicacabum Linn. has enormous medicinal value which is used to treat simple ailments to chronic diseases because of presence of their bioactive phytochemical constituents. This review throws light on the bioactivity potential of this easily available plant which may be beneficial to the society

\section{REFERENCES}

1. Raza SA, Hussain S, Riaz H, Mahmood S. Review of beneficial and remedial aspects of Cardiospermum halicacabum L. Afr J Pharmacol 2013;7 Suppl 48:3026-33.

2. Jeyadevi R, Sivasudha T, Ilavarasi A, Thajuddin N. Chemical constituents and antimicrobial activity of Indian green leafy vegetable Cardiospermum halicacabum. Indian J Microbiol 2013;53(1):208-13.

3. Senthilkumar S, Vijayakumari K. Phytochemical and GC-MS analysis of Cardiospermum halicacabum Linn. Leaf. Int J Inst Pharm Life Sci 2013;3 Suppl 5:95-8

4. Rajasekaran A, Kaliselvan V, Sarathikumar N, Kalaivani M. Simultaneous estimation of luteolin and apigenin in methanolic leaf extract of Cardiospermum halicacabum by HPLC. Int Res J Pharm 2013;4 Suppl 7:109-13.

5. Vinoth B, Manivasagaperumal R. Phytochemical analysis and antibacterial activity of Cardiospermum halicacabum Linn. Int J Curr Sci Technol 2013;2 Suppl 1:9-12.

6. Patil AG, Joshi KA, Patil DA, Chandra N. Pharmacological standardization and HPTLC fingerprint of Cardiospermum halicacabum L. Stem. Res J Pharm Biol Chem Sci 2011;2 Suppl 2:343-52.

7. Annadurai A, Elangovan V, Velmurugan S, Ravikumar R. Preliminary phytochemical screening and antibacterial activity of medicinal plant Cardiospermum halicacabum L. Adv Appl Sci Res 2013;4 Suppl 5:302-8

8. Rajesh S, Sivakumari K, Ashok K, Abitha AR. Anticancer activity of Cardiospermum halicacabum Linn. Leaf extracts against Hepatocellular carcinoma cell line $\left(\right.$ Hep- $\left.\mathrm{G}_{2}\right)$. World J Pharm Pharm Sci 2016;5 Suppl 3:1133-54

9. Aishwarya V, Abdulla SS, Dheeba B, Renuka R. In vitro antioxidant and anticancer activity of Cardiospermum halicacabum L. against EAC cell line. Int J Pharm Pharm Sci 2014;6 Suppl 8:263-8.

10. Viji M, Murugesan S. Phytochemical analysis and antibacterial activity of medicinal plant Cardiospermum halicacabum Linn. J Phytol 2010;2 Suppl 1:68-77.

11. Shareef H, Rizwani GH, Mahmood S, Khursheed R, Zahid H. Invitro Antimicrobial and Phytochemical analysis of Cardiospermum halicacabum L. Pak J Bot 2012;44 Suppl 5:1677-80.

12. Boonmars T, Khunkitti W, Sithithaworn P, Fujimaki Y. In vitro antiparasitic activity of extracts of Cardiospermum halicacabum against third-stage larvae of Strongyloides Stercoralis. Parasitol Res 2005;97 Suppl 5:417-9.

13. Huang MH, Huang SS, Wang BS, Wu CH, Sheu MJ, Hou WC, et al. Anti-oxidant and Anti-inflammatory properties of Cardiospermum halicacabum and its reference compounds ex vivo and in vivo. J Ethnopharmacol 2011;133 Suppl 2:743-50

14. Babu G, Sudhakaran R, Reddy CH. Phytochemical and pharmacological investigations of Cardiospermum halicacabum and Gymnema sylvestre. World J Pharm Pharm Sci 2014;3 Suppl 11:739-58.

15. Babu KC, Kumari SK. Cardiospermum halicacabum suppresses the production of TNF-alpha and nitric oxide by human peripheral blood mononuclear cells. Afr J Biomed Res 2006;9:95-9.

16. Babu KC, Krishnakumari S. Anti-inflammatory and antioxidant compound, rutin in Cardiospermum halicacabum leaves. Anc Sci Life 2005;25(2):47-9.

17. Shobanadevi S, Nandhini P, Tripathi H, Hari R. Antioxidant activity of combined ethanolic extract of Pisonia grandis and Cardiospermum halicacabum. Int J Pharm Sci Res 2016;39 Suppl 1:95-100.

18. Kumaran A, Karunakaran RJ. Antioxidant activities of the methanol extract of Cardiospermum halicacabum. J Pharm Biol 2006;44(2):146-51.

19. Molina V. DPPH radical scavenging activity and reducing power of balloon vine (Cardiospermum halicacabum Linn.) leaf extract. Int J
Trend Res Dev 2016;3 Suppl 3:531-3.

20. Annamalai A, Ponmari G, Sathishkumar R, Lakshmi PT. Effect of drying treatment on the contents of antioxidants in Cardiospermum halicacabum Linn. Int J Pharm Biosci 2011;2 Suppl 1:304-13.

21. Asha VV, Pushpangadan P. Antipyretic activity of Cardiospermum halicacabum. Indian J Exp Biol 1999;37:411-4.

22. Abdullahi AL, Agho MO, Amos S, Gamaniel KS, Wambebe C. Antidiarrhoeal activity of the aqueous extract of Terminalia avicennoides roots. Phytother Res 2001;15(5):431-4.

23. Prakash KC, Kuppast IJ. Antidiarrhoeal activity of Cardiospermum halicacabum and Dodonea Viscosa. Int J Pharm Sci 2014;6 Suppl 10:257-60.

24. Rao NV, Prakash KC, Kumar SM. Pharmacological investigation of Cardiospermum halicacabum (Linn.) in different animal models of diarrhoea. Indian J Pharmacol 2006;38 Suppl 5:346-9.

25. Narayani PC, Anbu J, Vasuk R, Hari R. In vitro and in vivo anti-arthritic activity of combined ethanolic extracts of Calotropis gigantean and Cardiospermum halicacabum in Wistar Rats. J Nat Remedies 2014; 14 Suppl 1:58-66.

26. Jeyadevi R, Sivasudha T, Rameshkumar A, Dineshkumar L.Anti-arthritic activity of the Indian leafy vegetable Cardiospermum halicacabum in Wistar rats and UPLC-QTOF-MS/MS identification of the putative active phenolic components. Inflamm Res 2013;62 Suppl 1:115-26.

27. Aiyalu R, Subramaniam I, Govindarajan A, Ramasamy A. Evaluation of synergistic effect of methanol leaf extract of Cardiospermum halicacabum and Vitex negundo on inflammation and arthritis. J Herbs Spices Med Plants 2014;20 Suppl 4:372-85

28. Aiyalu R, Govindarajan A, Ramasamy A. Formulation and evaluation of tropical herbal gel for the treatment of arthritis in animal model. Braz J Pharm Sci 2016;52 Suppl 3:493-507.

29. Kumar KE, Mastan SK, Reddy GA, Raghunandhan N, Sreekanth N, Chaitanya, G. Anti-arthritic property of the ethanolic leaf extract of Cardiospermum halicacabum Linn. Biomed Pharmacol J 2008;1 Suppl 2:467.

30. Padmini N, Sundaramoorthy SD, Tripathi $\mathrm{H}$, Hari. In vitro and in vivo anti-arthritic activity of combined ethanolic extract of Pisonia grandis and Cardiospermum halicacabum in Wistar rats. J Appl Pharm Sci 2016;6 Suppl 9:102-8

31. Selvi RS, Bai GV. A comparative study of anti-arthritic efficacy of Cardiospermum halicacabum (L) and Cissus vitiginia (L) freund's complete adjuvant induced arthritis. Int J Res Biol Sci 2014;4 Suppl 4:94-100.

32. Mahmood R, Najam R, Rizwani GH, Khatoon H. Evalution of neuropharmacological activity of Cardiospermum halicacabum (Linn.) leaf extract. World J Pharm Pharm Sci 2016;5 Suppl 3:896-906.

33. Malaviya SN, Andhakumar K, Vghasiya J, Bhalodiya Y, Jivani N, Sheth $\mathrm{N}$, et al. Anxiolytic activity of root extracts of Cardiospermum halicacabum in mice. Internet J Pharmacol 2009;7 Suppl 1:1.

34. Rajeshkumar G, Murugananthan G, Nandakumar K, Talwar S. Isolation of anxiolytic principle from ethanolic root extract of Cardiospermum halicacabum. Phytomedicine 2011;18 2 Suppl 3:219-23.

35. Sudha K, Mathangi SK. Functional compounds of some traditional greens and its medicinal properties. Int $\mathrm{J}$ Univ Pharm Biosci 2013;2 Suppl 4:267-92.

36. Stalin C, Vivekanandhan K, Bhavya E. In vitro antidiabetic activity of Cardiospermum halicacabum Leaves extract. Glob J Med Res B 2013;13 Suppl 7:41-3

37. Gandhi GR, Sasikumar P. Antidiabetic effect of Merremia emarginata Burm. F. in streptozotocin induced diabetic rats. Asian Pac J Trop Biomed 2012;2:281-6.

38. Veeramani C, Pushpavalli G, Pugalendi KV. Antihyperglycaemic effect of Cardiospermum halicacabum Linn. Leaf extract on STZ-induced diabetic rats. J Appl Biomed 2008;6:19-26.

39. Rajeswari R, Sridevi M. Study on in vitro glucose uptake activity of isolated compounds from hydroalcoholic leaf extract of Cardiospermum halicacabum Linn. Int J Pharm Pharm Sci 2014;6 Suppl 11:181-5.

40. Govindappa M.Areview on role of plant(s)extract and its phytochemicals for the treatment of diabetes. J Diabetes Metab 2015;6 Suppl 7:565.

41. Naik VK, Babu KS, Latha J, Prabakar V. A review on its ethnobotany, phytochemical and pharmacological profile of Cardiospermum halicacabum Linn. Int J Pharm Res Biosci 2014;3 Suppl 6:392-402.

42. Vetrichlvan T, Narasimhana CL, Venkatramani R. Antionvulsant action of petroleum ether fraction of Cardiospermum halicacabum against electroshock induced convulsion in rats. Ancient Sci Life 2000;19 3 Suppl 4:1-3

43. Kukkar MR, Saluja AK, Sachdeva PD, Kukkar RR. In vivo investigation of the neuroprotective potential of Cardispermum halicacabum Linn. 
Int J Pharm Pharm Sci 2014;6 Suppl 4:64-6.

44. Sagadevan P, Suresh SN, Rathishkumar S, Gayathri S, Eswari DV. Anticancer activity of methanolic leaf extract of Andrographis paniculata (Nees) and Cardiospermum halicacabum (Linn.) against human breast cell cancer cell line. (MCF-7). Int J Pharm Life Sci 2013;4 Suppl 9:2983-6.

45. Jacob B, Natarajan S, Pattiyappan S, Sivaraman R, Suresh MS. Study on anti-carcinogenic and apoptotic properties of methanolic stem extract of Cardiospermum halicacabum in MCF7 cell line. J Sci Innov Res 2015;4 Suppl 1:43-8.

46. Arunkumar S, Valentina P, Deepa G, Anitapriyadharshini K, Rekha D, Sreekiran M, et al. Preliminary phytochemical analysis, HPTLC finger printing and in vitro anticancer screening of extracts of aerial parts of Cardiospermum halicacabum. Int J Pharm Pharm Sci 2013;5 Suppl 3:301-4. 